\title{
Students Economic Empowerment through the Public Sphere
}

\author{
A Research in Universitas Islam Negeri Sunan Gunung Djati Bandung
}

\author{
Enok Risdayah, Asep Iwan Setiawan, Krisna Somantri, and Dedi Suyandi \\ Agama dan Media, Pascasarjana \\ UIN Sunan Gunung Djati \\ Bandung, Indonesia \\ enok.risdayah@uinsgd.ac.id
}

\begin{abstract}
This research was conducted at Universitas Islam Negeri Sunan Gunung Djati Bandung, where currently, there are more than twenty-four thousand students there. Through observations, the researchers found that some of the students used public space such as the mosque yard and the class yard for economic activities (for instance selling food and beverages). The data in this research were collected through observation and interview. Moreover, the data were qualitatively analyzed and narrated descriptively using critical theory and development model of achievement motivation. Through this critical paradigm, we will see how the students struggle in developing their talents, or their interest in the economic field, while their spaces are limited enough to do these things. Moreover, they must bet on buyer dishonesty and clash with restrictions issued by officials or power holders on campus regarding the rules of selling in those public spaces. The results of the research indicated that students' interest in developing the economic activities did increase both personally and in groups.
\end{abstract}

Keywords-Empowerment; Economy; Public Sphere

\section{INTRODUCTION}

Instead of being used as parking lots, the open mosque courtyard, the office building yard, and the classroom yard become spaces that are beneficial to some or a group of people especially those within the Universitas Islam Negeri Sunan Gunung Djati Bandung. The economic needs of some university's residents are fulfilled through these spaces. They sell the goods in the form of food, books, or anything else. They lined up their goods without paying attention to it and only stack the price of the goods there. Some of them complete their goods with money box where the buyer handed over the money and some of them are not, which lets the buyer put the money on the goods box. A unique economic transaction based on honesty.

Moreover, the college community is a community in the university where it administered a higher education. According to Article 19, Paragraph (1), Law Number 20 of 2003 about National Education System, a higher education is the level of education after secondary education which includes diploma education programs, scholars, master, specialists, and doctorate organized by universities. Universities administered by the government are called state universities (PTN) and the one that administered by the community, associations/foundations are called private universities (PTS). In addition, the university community at least consists of lecturers, students, and a set of structural managers/officials: rectorates, deans, bureaus/ sections/affairs, and so on. Further, if the definition of the university community is expanded, it can include all stakeholders such as parents or the guardians of the students.

The existence of students is one of the important element for an educational institution. Without the students, an educational institution or university will not be able to run well. At the same time, the existence of students is also an element of society in general. They are the next generation, the hope of the nation, and in their hands, the pillars of leadership and the fate of this country are located. Their gait and responsibility is the foundation. Moreover, the future of this country, whether it is good or bad is in their grasp.

The empowerment for students is important, especially for the students who economically are less, since the need for their life is not enough to rely on just the given from their parents. It is reasonable because there are many costs that must be issued considering that students' need to follow many activities all need some fees. To reach the solution, the students are required to be able to find another income. One way that is done so far by some students is entrepreneurship activities or selling in open spaces such as around mosques, classrooms, and other. Moreover, when it runs well and succeeds, the students feel helpful. However, the students may find some obstacles by selling the goods in those public spaces. Because, as it is known that, selling/muamalah around the mosque is not allowed in a sharia law as well as outside the classroom where it can disturb the beauty/aesthetics of the class. The students who sell the goods are still running their business and even more of them are coming and selling the goods in public spaces. In addition, the mosque allowed selling as long as not inside the mosque area. Moreover, the same thing also happened to the rectorate who did not give any action or prohibition for the students who sold in those areas. It is understandable considering there are some considerations, as long as the selling activities do not have a bad impact on all parties and all elements are able to maintain cleanliness. Further, it is fine because it applies the act of symbiotic mutualism, where besides the students do entrepreneurship, they also can learn independently as well as to help their economy condition. 


\section{RESEARCH METHOD}

Qualitative method was used in this research by describing the findings data found in the field then explaining the data through two way approach developed in the discussion of empowerment and public space. The approach used in empowerment is the theory of achievement motivation, which is a theory of motivation development by way of achievement. Students are encouraged and directed to continue to improve their business. The urge to finish the higher education on time always become a motivation that the independent life is much better than always expecting the compassion of others, and others.

The use of open spaces through a critical approach such as why some students are able to work in these places, while the other students do not, why one succeeds the other does not, why one can survive while the other cannot survive. Those questions are then answered through observations and interviews.

\section{RESUlT AND DisCUSSION}

From the results of interviews conducted by the authors, $60 \%$ of the total UIN SGD students come from a rural area with middle to lower economic level. Under such conditions, solutions are needed to help the difficulties they face especially in the economic field. But some of the difficulties faced by them have been overcome by themselves. Carefulness in seeing opportunities, ability in facing challenges, willpower and determination in striving for the ideals and hopes become the motivation for some students who directly or indirectly have entrepreneur sol. This is what is meant as empowerment, which means to maximize all the potential to achieve prosperity.

Empowerment is a concept of economic development that includes social values. This concept reflects a new paradigm of development, which is people-centered, participatory, empowering, and sustainable. This concept is broader and merely fulfills basic needs or provides a mechanism to prevent further neutralization, which has been widely thought to be an attempt to reach alternatives to past growth concepts. This concept was developed as an attempt by many experts and practitioners to find what among other things by Friedman called alternative development, which wants inclusive democracy, appropriate economic growth, gender equality and intergenerational equity. Moreover, community economic empowerment is strengthening the ownership of production factors, strengthening the distribution and marketing, strengthening the community to get adequate salary and wages, and strengthening the community to obtain information, knowledge, and skills, which must be done multi-aspect, both from the aspect of society itself and the policy aspect. Empowerment becomes a keyword that is considered able to overcome all the problems of development. The problem of empowerment is often used by those who have power as a symbol of awareness, charity program, social responsibility and partisanship to the community. The empowerment process is a cycle or process that involves the community to cooperate with formal and non-formal groups to conduct problem studies, plan, implement and evaluate programs that have been planned together.
For the agrarian popularism group, empowerment is one of the proposed solutions in order to eradicate poverty. For them, the society (in this case the student) is a person or group who can build himself if they are given the freedom to regulate himself.

Conceptually, empowerment is closely related to power, as a public policyholder. Empowerment was born as an antithesis to the development model and the industrialization model that is less favorable to the majority. This concept builds on the logical framework as follows: (1) that the centralizing process of power is built up from the concentration of mastery of the factors of production; (2) concentration of power on production will give rise to workers' and society's periphery entrepreneurs; (3) power will build a top building or a system of knowledge, a political system, a legal system, and a manipulative ideology for strengthening and legitimacy; and (4) co-optation of knowledge systems, legal systems, political systems, and ideologies, will systematically create two groups of people, namely powerful society and powerless society .

In the application of the concept of empowerment, it is divided into two parts, namely a powerful society and powerless society, in this case, the powerful students and powerless students. Powerful society is human beings who capable of carrying out their dignity as human beings, independent in acting as human beings based on common sense and conscience.

Powerful students are students who have the will and ability to see opportunities, skilled in handling challenges, taking and managing them in accordance with what is needed. The need for tuition fees encourages some students to enter the business world or entrepreneurship. The entrepreneur's activity they are doing also relatively without capital money, usually only with energy and honesty. They sell by taking the goods from the first manufacturer, without saving capital first. Payments are made after the goods is sold. Thus, there is a wide range of opportunities for students to do entrepreneurship, provided they have a willingness and earnest in the activities. However, in reality, there are not many students who have the power/power as described above, the results show only $0.00001 \%$ of the total overall who have tried to wrestle in the field of entrepreneurship. This is certainly caused by several factors both internal and external.

Formally, the curriculum policy has encouraged students to follow that direction, by providing entrepreneurship courses as compulsory courses ideally presented throughout the course of study at this university. In real terms, there are 16 students who use public spaces for selling the goods. These places include: outside the classroom of Faculty of Ushuluddin, Faculty of Dakwah and Communication, Faculty of Adab and Humanities, Faculty of Syariah and Law, Faculty of Psychology, Faculty of Science and Technology and Faculty of Social and Political Sciences. Thus, throughout the classroom in all faculties are utilized by students to do the entrepreneurship activity. The student who involves in this activity almost represents every faculty, for example, Abdul Rahman, a student of Management Dakwah in Faculty of Dakwah and Communication on the sixth semester, he sells donut in the class yard of Faculty of Dakwah. Another one is 
Syifa, a student of Faculty of Psychology on the sixth semester who sell food outside the classroom in her faculty.

The class yard is one of the public spaces used by students to gather, chat, joke, discuss and discuss various lecture-related matters or possible problems outside the lecture. As if the English cafes or beauty salons in France in the 18th century. Between the state (political space) and the people/family (private-domestic space), there is a middle term that bridges the public space (civil society). This space is universal and distinct from the particular private space. Public space is a discursive space where groups of people can come together to discuss what they want to discuss, and wherever possible to a particular decision. Decisions to sell foods and beverages in these spaces are the result of communication both interpersonal and intrapersonal.

Public spaces serve as a media for achieving and creating effective communication at least between sellers and buyers in the classroom.Public space is a space that can accommodate the interests of the public or the general public, such as communicating with colleagues, meeting certain community informal, play, walk, unwind, and see the park and afforestation. The development of public space shows a process of community leading to communication skills.

The idea of a public space or public sphere was first introduced by Jurgen Habermas through his book Strukturwandel der Öffentlichkeit; Untersuchunge knows zu einer Kategorie der Bürgerlichen Gesellschaft. The English edition of this book, The Structural Transformation of the Public Sphere: an Inquiry into a Category of Bourgeois Society, published in 1989. Habermas explains that public space is a media for communicating the information as well as views. As depicted in England and France, people meet, chat, discuss newly published books or newly created works of art. In the state of society meet and argue about something critically will form what is called the civil society. In the development of public space, it is not only developing physically but also on social media. Student traders in UIN Bandung incorporated in some WhatsApp group, they take advantage of this technology to make their business run well.

Getting a free stall is certainly not an easy matter, especially for new traders. They have to go through the agreement with the old traders, as well as the type of goods are traded, it must be different from one another, this is the strategy that is applied in order to avoid unhealthy competition, so it takes carefulness in choosing the type of goods they are going to sell.

In addition to the class yard, the mosque's yard became one of the preferred places for students to trade, even though there is now a ban on selling around the mosque. The goods are traded all in the form of food, ranging from types of snacks such as donuts, various types of fried foods (bala-bala, gehu, comro, basreng, risoles), and other foods such as cilok. Heavy meals also available to buy there such as leupeut, uras, yellow rice, and so on.

The trade system is unique, the goods that will be sold are listed on the floor unattended by the sellers, the buyers are free to choose the type of goods needed, as, in supermarkets, the price of merchandise is simply written on a piece of paper or on the top of the crib. Through that writing, the buyer knows and understands the message submitted by the seller. An effective form of verbal communication conveys a message to consumers. To anticipate losses, control is done in turns at the end of the lecture by one of the traders who are not in the university. In addition, to utilize the use of CCTV, CCTV installed by the university management. According to the buyers, the presence of snacks in front of the class is very helpful, they do not have to find food if they have not had breakfast yet or just snacking at the end of the lecture.

According to the confessions of the sellers, they do not always fare well, sometimes the goods are gone without money, this means a loss, but they do not deter the event, the next day they re-held the gods. This is what made them successful, the ups and downs faced with patience, tenacity and relieved.

\section{CONCLUSION}

Higher Education is an educational institution which consists of a set of educational managers, lecturers, and students. As we know that students who are studying in higher education do not all have established economic background, one of them at Universitas Islam Negeri Sunan Gunung Djati Bandung where almost $60 \%$ of the total students come from a rural area with middle to lower economic level. Therefore, there are some group of students who conduct business activities/entrepreneur. Moreover, this entrepreneur activity can produce and help students' economy and students' family that indirectly can lighten the burden of their parents. Likewise, the students cannot sue their parents to meet their life needs during university. With the entrepreneurial spirit and carefulness to see the opportunities, hard work and motivation to achieve the goals, this can be a support for students to achieve prosperity because they have tried to optimize all their potential. One of the efforts done by the students in the business of buying and selling food and beverages. This entrepreneurship activity is generally done without large capital and even without capital at all because the goods sold is the production of others and students only responsible to sell it. Moreover, the payment is made after the goods are sold. In addition, they didn't use stalls because they are using public spaces around campus, so there is no investment capital or rental places. System sales are also conducted on the basis of honesty, this is a unique thing done by the students in entrepreneurship. The pattern of business without capital through economic empowerment in public space has now been present in the midst of students of the Universitas Islam Negeri Sunan Gunung Djati Bandung, a positive creativity and provide many benefits.

\section{REFERENCES}

[1] Dannawan, E. (2005). Ruang Publik dan Kualitas Ruang Kota, Proceeding. Seminar Nasional PESAT 2005.

[2] Hafsah, M.J. (2008). Pengentasan Kemiskinan Melalui Pemberdayaan Masyarakat. Bandung: Institut For Religius and Institutional,Iris.

[3] Harahap, E.F. (2012). Pemberdayaan Masyarakat dalam Bidang Ekonomi untuk Mewujudkan Ekonomi Nasional yang Tangguh dan Mandiri. Jurnal Manajemen dan Kewirausahaan, 3(2). ISSN 2086-5031. 
[4] Hardiman, F. B, ed. (2010). Ruang Publik,Melacak Partisipasi demokratis dari Polis Sampai Cyberspace. Jogjakarta: Kanisius.

[5] Huriyudin dan Muchtamil ed. (1999). Model Pengentasan Kemiskinan Melalui Jalur Agama, Jakarta: DEPAG RI Badan Penelitian dan Pengembangan Agama Proyek Penelitian Keagamaan.

[6] Jamasy, O. (2004). Keadilan, Pemberdayaan dan Penanggulangan Kemiskinan. Jakarta: Belantika (PT. Mizan Publika).

[7] Moleong, J. L. (1989). Metode Penelitian kualitatif. Bandung: PT Remaja Rosda Karya.

[8] Projono, O.S dan Pranarka, A.M.W. (1996). Pemberdayan: Konsep Kebijakan dan Implementasi. Jakarta: CSIS.
[9] Suharto, E. (2005). Membangun Masyarakat Memberdayakan Rakyat, Bandung: PT. Refika Aditama,

[10] Supriyadi, Y. (2017). Relasi Ruang Publik Dan Pers Menurut Habermas Kajian Jurnalisme, 1(1). ISSN 2549-0559 (cetak) ISSN 2549-1946 (online).

[11] Tobirin. (2013). Formalitas dan Simbolisasi Politik Pemberdayaan Masyarakat Dalam Pengentasan Kemiskinan di Pedesaan, Jurnal Masyarakat, Kebudayaan dan Politik, 26(4).

[12] Widjajanti. (2011). Model Pemberdayaan Masyarakat. Jurnal Ekonomi Pembangunan, 12(1) 